\title{
Article \\ Oyster Shell Powder, Zeolite and Red Mud as Binders for Immobilising Toxic Metals in Fine Granular Contaminated Soils (from Industrial Zones in South Korea)
}

\author{
Cecilia Torres-Quiroz $^{1}\left(\mathbb{D}\right.$, Janith Dissanayake $^{1(\mathbb{D})}$ and Junboum Park ${ }^{1,2, *(D)}$ \\ 1 Department of Civil and Environmental Engineering, Seoul National University, 1 Gwanak-ro, Gwanak-gu, \\ Seoul 08826, Korea; ctorresq@snu.ac.kr (C.T.-Q.); janith1993@snu.ac.kr (J.D.) \\ 2 Institute of Construction and Environmental Engineering, Seoul National University, 1 Gwanak-ro, \\ Gwanak-gu, Seoul 08826, Korea \\ * Correspondence: junbpark@snu.ac.kr; Tel.: +82-02-880-8356
}

check for updates

Citation: Torres-Quiroz, C.; Dissanayake, J.; Park, J. Oyster Shell Powder, Zeolite and Red Mud as Binders for Immobilising Toxic Metals in Fine Granular Contaminated Soils (from Industrial Zones in South Korea). Int. J. Environ. Res. Public Health 2021, 18, 2530. https://doi.org/10.3390/ ijerph18052530

Academic Editor: Paul Tchounwou

Received: 9 February 2021

Accepted: 27 February 2021

Published: 4 March 2021

Publisher's Note: MDPI stays neutral with regard to jurisdictional claims in published maps and institutional affiliations.

Copyright: (c) 2021 by the authors. Licensee MDPI, Basel, Switzerland. This article is an open access article distributed under the terms and conditions of the Creative Commons Attribution (CC BY) license (https:/ / creativecommons.org/licenses/by/ $4.0 /)$.

\begin{abstract}
Low-cost absorbent materials have elicited the attention of researchers as binders for the stabilisation/solidification technique. As, there is a no comprehensive study, the authors of this paper investigated the performance of Oyster shell powder (OS), zeolite (Z), and red mud (RM) in stabilising heavy metals in three types of heavy metal-contaminated soils by using toxicity characteristic leaching procedure (TCLP). Samples were collected from surroundings of an abandoned metal mine site and from military service zone. Furthermore, a $\mathrm{Pb}$-contaminated soil was artificially prepared to evaluate each binder $(100 \times$ regulatory level for $\mathrm{Pb})$. OS bound approximately $82 \%$ of $\mathrm{Pb}$ and $78 \%$ of $\mathrm{Cu}$ in real cases scenario. While $\mathrm{Z}$ was highly effective in stabilizing $\mathrm{Pb}$ in highly polluted artificial soil $(>50 \%$ of $\mathrm{Pb}$ ) at lower dosages than OS and $\mathrm{RM}$, it was not effective in stabilising those metals in the soils obtained from the contaminated sites. RM did not perform consistently stabilising toxic metals in soils from contaminated sites, but it demonstrated a remarkable $\mathrm{Pb}$-immobilisation under dosages over than $5 \%$ in the artificial soil. Further, authors observed that OS removal efficiency reached up to $94 \%$ after 10 days. The results suggest that OS is the best low-cost adsorbent material to stabilize soils contaminated with toxic metals considered in the study.
\end{abstract}

Keywords: low-cost absorbent; stabilization and solidification; toxic metal; chemical stabilization; leaching test; TCLP; remediation

\section{Introduction}

Soil contaminated with toxic metals is a serious environmental issue worldwide [1,2]. Toxic metals exhibit the potential of affecting the soil-food chain, impairing soil fertility [3-5] and the quality of drinking water [6]. Once they enter the food chain, toxic metals can trigger cell mutation, possibly causing cancer $[5,7,8]$. Amongst these metals, $\mathrm{Pb}$, $\mathrm{Cd}, \mathrm{Cu}, \mathrm{Zn}$ and $\mathrm{Ni}$ have elicited considerable concern because they are leached from tailings and discharged directly into adjacent streams and agricultural lands [9]. Numerous remediation techniques are available for remediating soil contaminated with toxic metals. They include surface capping [10], encapsulation [11,12], landfilling, soil flushing [13], soil washing [14,15], electrokinetic extraction [16-18], stabilisation/solidification (S/S) [19-21], vitrification [22,23], phytoremediation [24,25] and bioremediation. Amongst these techniques, $\mathrm{S} / \mathrm{S}$ has attracted the attention of many researchers due to its low-cost application whilst preserving the long-term stability of the stabilised soil [26,27]. This technique involves the addition of binding materials (binders) to contaminated soil to stabilise and immobilise contaminants [28-30] via the chemical fixation of pollutants. This process is achieved through the interactions between the hydration products of binders and contaminants or the physical adsorption of contaminants [27,31]. The addition of lime, cement and other cementitious binders to soil has demonstrated excellent performance in treating 
soil contaminated with toxic metals [32]. However, stabilising wide areas of polluted soil by using such cementitious materials is economically infeasible due to the cost associated with such binders. To address this issue, many researchers have investigated nature-based materials, such as chitosan [33], zeolite [34], compost [35], hydroxyapatite [32] and waste products from certain industries, including fly ash [29,36], oyster shell powder [37,38], red mud $[39,40]$ and coal, for their potential use as binders. At present, these materials have gained popularity as binders because of their local availability and low cost $[26,30]$. Oyster shell have been investigated for its interactions with toxic metal ions in an aqueous medium $[38,41,42]$. However, only a few researchers have investigated its application to soil [30,43-45]. The sorption characteristics and cation exchange capacity of zeolite has been studied extensively for its potential in removing toxic metals from water [34,46-49]. Similar to oyster shell, zeolite has not been investigated in terms of its use in remediating soil, although a few studies, such as those of Kwon et al. [50] and Wen and Zeng [51], investigated this subject. Red mud; Bauxite residue produced during Alumina production [41] is a relatively new material that has gained popularity in remediating soil [39]; however, its application has been limited due to the health risks associated with its use [52,53]. Some researchers have demonstrated that oyster shell, zeolite and red mud can be used as binders due to their sorption characteristics. Nevertheless, the literature on assessing their performance under various environmental settings is scarce. The characteristics of the medium, such as $\mathrm{pH}, \mathrm{Fe}_{2} \mathrm{O}_{3}$ content and redox potential, can influence the binding process of these materials [21,54]. Water percolation enhances metal mobilisation in already stabilised soil because the $\mathrm{H}^{+}$ions in acidic water displace the cations from their binding sites and reduce cation exchange capacity in accordance with Zheng et al. [31]. Thus, investigating the performance of these binders in leaching is crucial.

As granular soils have a poor capacity to retain these toxic metals, the binders could be used to stabilize soils quickly before the metals leach into ground water levels. Therefore, the current study investigated the performance of oyster shell, zeolite and red mud in stabilising two actual samples of sandy soil contaminated with toxic metals at the laboratory scale, with the pollution levels close to permissible limits. Furthermore, the authors examined the performance of these binders in stabilising soil with high $\mathrm{Pb}$ concentration by applying binders to a handmade contaminated soil. $\mathrm{Pb}$ is frequently found in high concentrations in contaminated sites worldwide [55], and it could be immobilised using the binders considered in the current study. Therefore, the authors performed leaching tests by using deionised (DI) water and the toxicity leaching characteristic procedure (TCLP) to observe the performance of oyster shell, zeolite and red mud as binder stabilisers for remediating the three types of soil. Furthermore, the influences of contact time and soil pH on the performance of these binders were investigated.

\section{Materials and Methods}

\subsection{Contaminated Soil Samples}

Soil samples were collected from two sites contaminated with toxic metals, namely, soil from surroundings of an abandoned metal mine site that was classified as silty sand (SM) with a fine content of $22 \%$ (denoted as "silty sand") and soil from a military service area that was classified as well-graded sand (SW) with a fine content lower than $5 \%$ (denoted as "sandy soil"). The sites are respectively located at 62,26 beon-gil, Gaegeumonjeong-ro, Gaegeum-dong, Busan, and San 65-1, Jangan-ri, Jangan-eup, Gijanggun, Busan, South Korea. All the soil samples were air-dried and passed through a $2 \mathrm{~mm}$ mesh prior to preliminary analysis and experiments. The preliminary tests indicated that the soil samples had toxic metal concentrations closer to the regulation level. Therefore, handmade contaminated sand soil (HCS) was prepared at $100 \times$ the maximum permissible level for $\mathrm{Pb}$, i.e., $3 \mathrm{mg} / \mathrm{L}$, in accordance with the Korean regulation level to evaluate binder performance under high $\mathrm{Pb}$ concentrations.

In the absence of standard methods for preparing contaminated soils, HCS was prepared following an approach similar to that of Martini and Shang [56]. HCS was made 
by mixing $4 \mathrm{~kg}$ of residual weathered soil (passed through a $2 \mathrm{~mm}$ mesh) classified as well-graded sand with $\mathrm{Pb}$ solution. Firstly, the weathered soil was sieved and analysed for the presence of toxic metals to determine the initial concentrations of the considered metals. Secondly, $67 \mathrm{~g}$ of $\mathrm{PbCl}_{2}$ was dissolved in $2 \mathrm{~L}$ of DI water. The solution was introduced into the soil and thoroughly mixed using an electric mixer until homogeneous slurry was achieved. The slurry was kept at room temperature for 2 days and then dried at $100{ }^{\circ} \mathrm{C}$ for $24 \mathrm{~h}$. Lastly, the spiked soil mixture was homogenised by diagonally flipping it 3-5 times on a plastic sheet. The soil samples were kept at room temperature until the experiment was performed. The major chemical compounds observed in each soil are listed in Table S1

\subsection{Binders}

Oyster shell powder (Jisan Industrial Co., Ltd., Busan, Korea with 89.3\% $\mathrm{CaCO}_{3}$ ), natural zeolite (Silicon dioxide 61\%, Mordenite 23.8\%, Heulandite-Ca 15.4\%; from Geumnong Industrial Co., Ltd., Pohang, Korea) and Red mud (Sanha E\&C Co., Ltd., Gyeonggi, Korea) were evaluated via energy-dispersive X-ray spectroscopy (EDS) to determine the chemical composition of these binders. The major chemical compounds observed in each binder are listed in Table S1. This chemical composition coincides with the findings of Shin, et al. [41], $\mathrm{Xu}$, et al. [42] and Lu, et al. [38]. Moreover, the structure of each binder (i.e., surface and porosity) was observed in macroscale via scanning electron microscopy (SEM) (Figure 1). All the binders were washed with DI water, dried, and sieved (through a $0.15 \mathrm{~mm}$ mesh). Besides, the initial $\mathrm{pH}$ of Red Mud was lowered to 8.5-9 prior to by using $1 \mathrm{M} \mathrm{HCL}$.
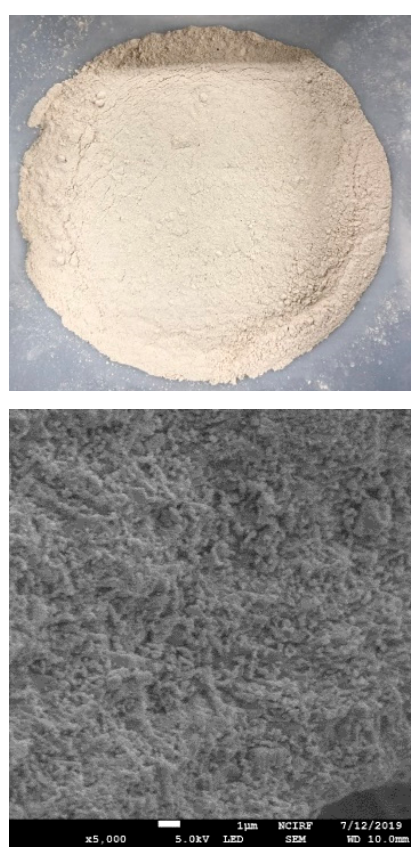

(a)
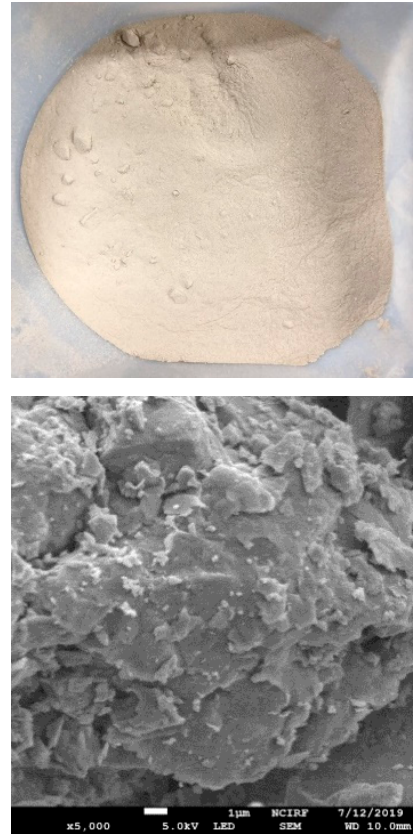

(b)
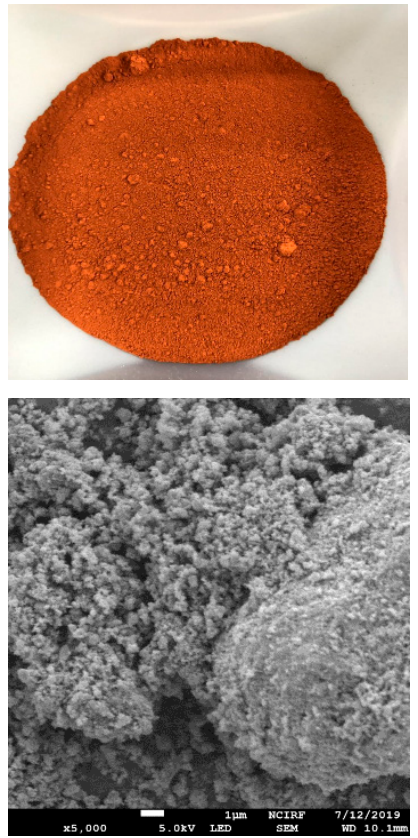

(c)

Figure 1. Materials texture and SEM analysis of the binder stabilisers considered in the study (5000×) (a) Oyster shell powder (OS); (b) Zeolite (Z) and (c) Red Mud (RM).

\subsection{Binder Performance Evaluation Method}

In the current study, leaching with DI water following a procedure similar to that used in HJ-557-2010 [57] accelerated the mixing of soil treated with a binder. The liquid: solid ratio (L/S) and mixing time presented in HJ-557-2010 was adjusted to obtain a homogeneous mixture of soil and binder. Firstly, a batch leaching tests with the modified DI water leaching procedure was performed on the control samples (i.e., contaminated soil without binder). 
The experiment procedure is described as follows. All the samples were tested at least in duplicate.

1. The test was initiated by taking samples of $50 \mathrm{~g}$ of air-dried soil as the control and measuring the initial toxic metal concentrations ( $\mathrm{Pb}, \mathrm{Cu}, \mathrm{Zn}, \mathrm{Cd}$ and $\mathrm{Ni}$ ). Then, $50 \mathrm{~g}$ of stabilised soil under different binder dosages per total weight $(1,3,5,7$ and $10 \mathrm{wt} \%)$ was placed in a $250 \mathrm{~mL}$ glass flask and agitated for $2 \mathrm{~h}$ at $150 \mathrm{rpm}$ with DI water at an $\mathrm{L} / \mathrm{S}$ of 3 .

2. The supernatant fluid from the previous step was extracted $8 \mathrm{~h}$ after Step 1 . For silty sand soil, however, additional extractions were performed at 12, 24 and $36 \mathrm{~h}$ after the first extraction to evaluate the effect of contact time with the binder on soil. After the supernatant fluid was extracted, it was filtered using a $0.45 \mu \mathrm{m}$ membrane filter and then collocated in a $14 \mathrm{~mL}$ tube for toxic metal $(\mathrm{Pb}, \mathrm{Cu}, \mathrm{Zn}, \mathrm{Cd}$ and $\mathrm{Ni})$ concentration measurement via inductively coupled plasma optical emission spectroscopy (ICPOES). Furthermore, $\mathrm{pH}$ was measured using a Thermo Scientific Orion 5-Star Plus Portable $\mathrm{pH} / \mathrm{ORP} / \mathrm{ISE} / \mathrm{Conductivity/DO}$ Multiparameter Meter Model Number: PH3642-2(Beverly, MA, USA) as presented in Table S2.

3. The control samples (without binder) and stabilised soil (after Step 2, solid phase) were placed in an oven and dried at $60{ }^{\circ} \mathrm{C}$ for $24 \mathrm{~h}$.

4. TCLP test was conducted on all the soil samples obtained after Step 3.

TCLP test was performed to measure toxic metal concentration in accordance with the U.S. EPA Method 1311 [58,59] because $\mathrm{CH}_{3} \mathrm{COOH}$, as an extract reagent, achieves better harmonisation during the laboratory testing of leaching compared with other reagents, such as EDTA [60]. Furthermore, acetic acid was used as the reagent because it represents a scenario in which organic acids are found in leachates from landfills [55].The steps for the TCLP test are described as follows.

5. A 2 g sample (from Step 3) was placed in small tubes that contained $40 \mathrm{~mL}$ of the extract solution $(\mathrm{L} / \mathrm{S}=20)$. Extract solution type depends on the $\mathrm{pH}$ of the medium (previously measured in Step 2).

6. After mixing thoroughly using a rotary tumbler at $30 \pm 2 \mathrm{rpm}$ for $18 \mathrm{~h}$, the samples were allowed to settle for $12 \mathrm{~h}$. Then, the supernatant fluid was extracted and sieved using a $0.45 \mu \mathrm{m}$ membrane filter and collocated in tubes with a $14 \mathrm{~mL}$ capacity to measure toxic metal concentration via ICP-OES. For the HCS treated with oyster shell, additional extractions were performed after 1 day and 10 days of mixing to evaluate the effect of contact time.

7. Lastly, the $\mathrm{pH}$ of the leachate was measured and reported in Table S3. A summary of the experiment procedure is presented as Figure 2.

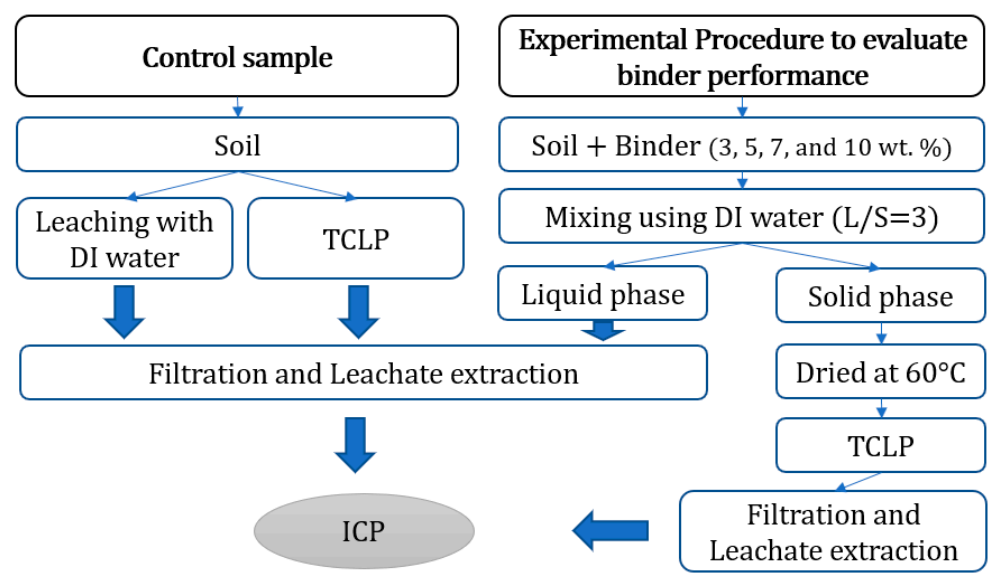

Figure 2. An overview of the experimental procedure for both the control sample (without binder) and soil after stabilized with the binder. 


\subsection{Measurement of Initial Toxic Metal Concentrations}

The physiochemical properties and initial toxic metal concentrations of all the soil samples are presented in Table 1 . The concentrations measured in the leachate $(\mathrm{mg} / \mathrm{L})$ via ICP-OES was converted into $\mathrm{mg} / \mathrm{kg}$ by using Equation (1) in the Korean standard procedure ES 07400.2c [61]. The same method was described [62-64].

$$
C_{\left(\frac{\mathrm{mg}}{\mathrm{kg}}\right)}=\frac{\left(C_{1}-C_{0}\right)}{W_{d}} \times f \times V
$$

where

$C_{1}$ : metal concentration of the analytical specimens obtained from the calibration curves $(\mathrm{mg} / \mathrm{L})$,

$\mathrm{C}_{0}$ : metal concentration of the blank solution obtained from the calibration curve $(\mathrm{mg} / \mathrm{L})$, $f$ : dilution rate,

$V$ : volume of the specimen container and

$W_{d}$ : dry weight of the soil specimen

The toxic metal concentrations prior to the addition of a binder converted as a fraction of mass $(\mathrm{mg} / \mathrm{kg})$ are provided in Table 1.

Table 1. Physiochemical properties of silty sand soil, sandy soil and handmade HCS; toxic metal concentrations in leachates before binder application.

\begin{tabular}{|c|c|c|c|c|c|c|c|c|c|}
\hline \multirow{2}{*}{ Source } & \multirow{2}{*}{ USCS $^{1}$} & \multirow{2}{*}{$\mathrm{pH}$} & \multirow{2}{*}{$\begin{array}{l}\text { Extraction } \\
\text { Method }\end{array}$} & \multirow{2}{*}{$\begin{array}{l}\text { Extract } \\
\text { Fluid }{ }^{2}\end{array}$} & \multicolumn{5}{|c|}{ Initial Concentrations } \\
\hline & & & & & $\mathrm{Pb}$ & $\mathrm{Cu}$ & Zn & $\mathrm{Cd}$ & $\mathbf{N i}$ \\
\hline \multirow{3}{*}{$\begin{array}{c}\text { Case I: } \\
\text { Mine area }\end{array}$} & \multirow{3}{*}{ SM } & \multirow{3}{*}{8.1} & $\begin{array}{c}\mathrm{DI} \\
\left(\mathrm{mg} \mathrm{L}^{-1}\right)\end{array}$ & DI & 0.015 & 0.110 & 0.045 & 0.002 & - \\
\hline & & & $\begin{array}{c}\text { TCLP } \\
\left(\mathrm{mg} \mathrm{L}^{-1}\right)\end{array}$ & I & 0.639 & 3.954 & 102.784 & 0.316 & 0.432 \\
\hline & & & $\begin{array}{c}\text { TCLP } \\
\left(\mathrm{mg} \mathrm{Kg}^{-1}\right)\end{array}$ & & 12.780 & 79.080 & 2055.680 & 6.320 & 8.640 \\
\hline \multirow{3}{*}{$\begin{array}{c}\text { Case II: } \\
\text { Military area }\end{array}$} & \multirow{3}{*}{ SW } & \multirow{3}{*}{6.7} & $\begin{array}{c}\mathrm{DI} \\
\left(\mathrm{mg} \mathrm{L}^{-1}\right)\end{array}$ & DI & 0.550 & 0.210 & 0.450 & 0.003 & - \\
\hline & & & $\begin{array}{c}\text { TCLP } \\
\left(\mathrm{mg} \mathrm{L}^{-1}\right)\end{array}$ & I & 0.079 & 2.235 & 10.053 & 0.046 & - \\
\hline & & & $\begin{array}{c}\text { TCLP } \\
\left(\mathrm{mg} \mathrm{Kg}^{-1}\right)\end{array}$ & & 1.580 & 44.700 & 201.060 & 0.920 & - \\
\hline \multirow{3}{*}{ Case III: HCS } & \multirow{3}{*}{ SW } & \multirow{3}{*}{4.9} & $\begin{array}{c}\mathrm{DI} \\
\left(\mathrm{mg} \mathrm{L}^{-1}\right)\end{array}$ & DI & 301.657 & 0.440 & - & - & \\
\hline & & & $\begin{array}{c}\text { TCLP } \\
\left(\mathrm{mg} \mathrm{L}^{-1}\right)\end{array}$ & II & 159.802 & 0.444 & - & - & - \\
\hline & & & $\begin{array}{c}\text { TCLP } \\
\left(\mathrm{mg} \mathrm{kg}^{-1}\right)\end{array}$ & & 3196.04 & 8.880 & - & - & - \\
\hline
\end{tabular}

${ }^{1}$ Unified Soil Classification System-USCS; ${ }^{2}$ USEPA Method 1311.

\section{Results}

3.1. Effects of Binder and Dosage

3.1.1. Case I: Silty Sand Soil from an Abandoned Metal Mine Site

The silty sand soil had an initial $\mathrm{pH}$ between 7.97 and 8.29 due to the presence of $\mathrm{CaO}$ (Table 1). When mixed with different dosages of oyster shell, zeolite and red mud, the $\mathrm{pH}$ of the soil changed to $7.87-8.18,7.60-7.81$ and 7.89-9.12, respectively (Table S2). The dosages of oyster shell and zeolite exerted no significant effect on the $\mathrm{pH}$ of this soil, whereas red mud dosage had a significant effect on $\mathrm{pH}$.

We observed that this soil had an initial $\mathrm{Cu}$ concentration (Table 1 ) that exceeded the South Korean regulation value for leachate and the World Health Organization (WHO), Australian and Canadian guideline values for soil (Table S4). Moreover, the silty sand soil contained $\mathrm{Cd}$ and $\mathrm{Zn}$ concentrations beyond the recommended guideline values. 
Other toxic metal concentrations were below the guideline limits. After adding $5 \mathrm{wt} \%$ of oyster shell, the concentration of $\mathrm{Cu}$ in the leachate was reduced from $3.954 \mathrm{mg} / \mathrm{L}$ to $0.937 \mathrm{mg} / \mathrm{L}$ (i.e., a reduction of $76 \%$, Figure S1), which is below the Korean regulation $(<3 \mathrm{mg} / \mathrm{L})$ and the limits stipulated by WHO (Table S4) (Figures 3 and S2). Zn was reduced from $102.784 \mathrm{mg} / \mathrm{L}$ to $68.657 \mathrm{mg} / \mathrm{L}$, which is also under relevant limits (Table S4). Moreover, Cd concentration in the leachate decreased from $0.316 \mathrm{mg} / \mathrm{L}$ to $0.182 \mathrm{mg} / \mathrm{L}$, satisfying the condition for toxic metal presence in wastewater [65]. Although the initial $\mathrm{Pb}$ and $\mathrm{Ni}$ concentrations were below the regulatory values, their concentrations were also reduced with increasing oyster shell dosage (Figures 3 and S2). In the case of zeolite, a dosage of $1 \mathrm{wt} \%$ reduced $\mathrm{Cu}$ and $\mathrm{Pb}$ concentrations by $50 \%$; thereafter, binder dose exerted no further effect (Figures 3 and S2). This phenomenon was also observed for $\mathrm{Zn}$ and $\mathrm{Ni}$ with a dosage of over $3 \mathrm{wt} \%$. Furthermore, zeolite appeared ineffective in binding $\mathrm{Cd}$ in soil at any dosage. Although the leachates from the soil were stabilised with zeolite at concentrations below the relevant guidelines (except for $\mathrm{Cd}$ ), the reduction was considerably lower compared with that of oyster shell. However, the leachate from the silty sand soil mixed with red mud presented a higher amount of $\mathrm{Cd}$ than the initial concentration, suggesting the poor adsorption of $\mathrm{Cd}$ by red mud (Figures 3 and S2). A dosage of $3 \mathrm{wt} \%$ was effective for stabilising $\mathrm{Cu}$ and $\mathrm{Zn}$, whilst increasing the dosage from $3 \mathrm{wt} \%$ to $5 \mathrm{wt} \%$ yielded no significant benefit $(p>0.05)$. Similar to oyster shell, the performance of red mud in binding $\mathrm{Pb}$ and $\mathrm{Ni}$ increased with dosage.
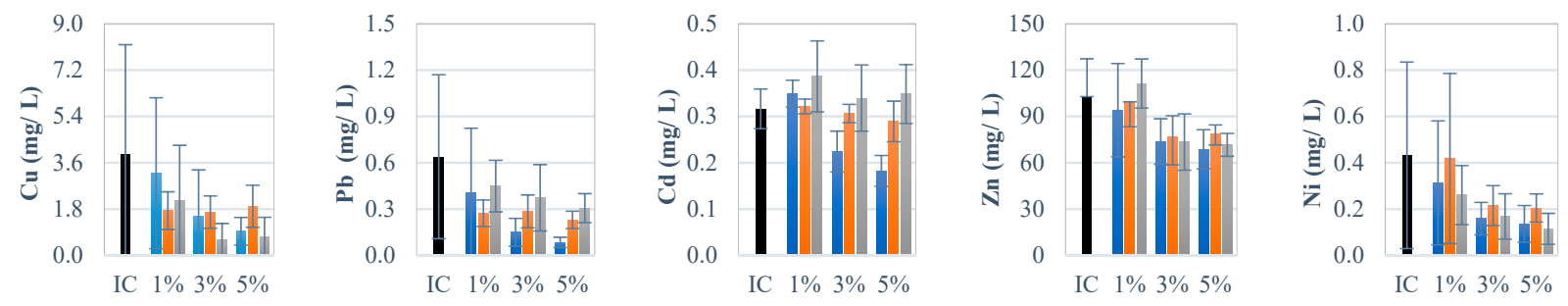

(a) Abandoned metal mine site (silty sand soil)
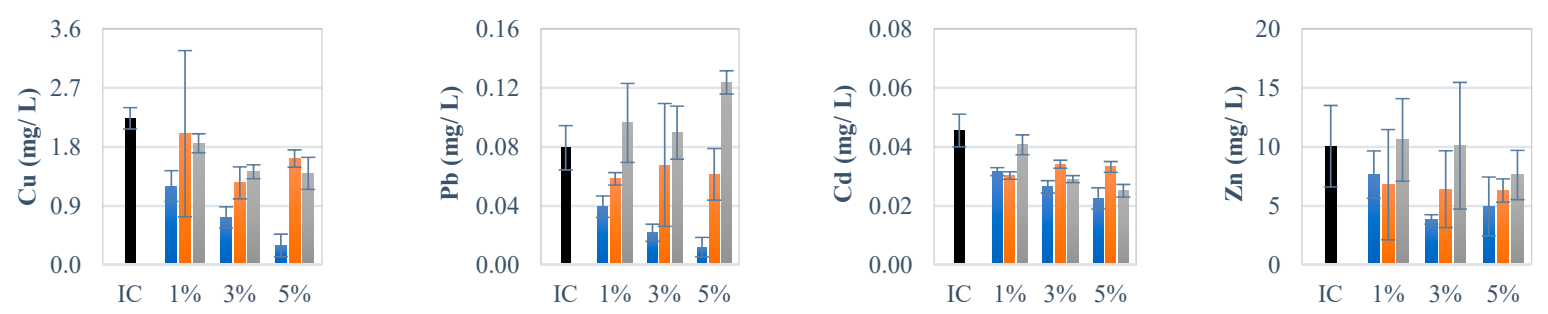

(b) Military service area (sandy soil)
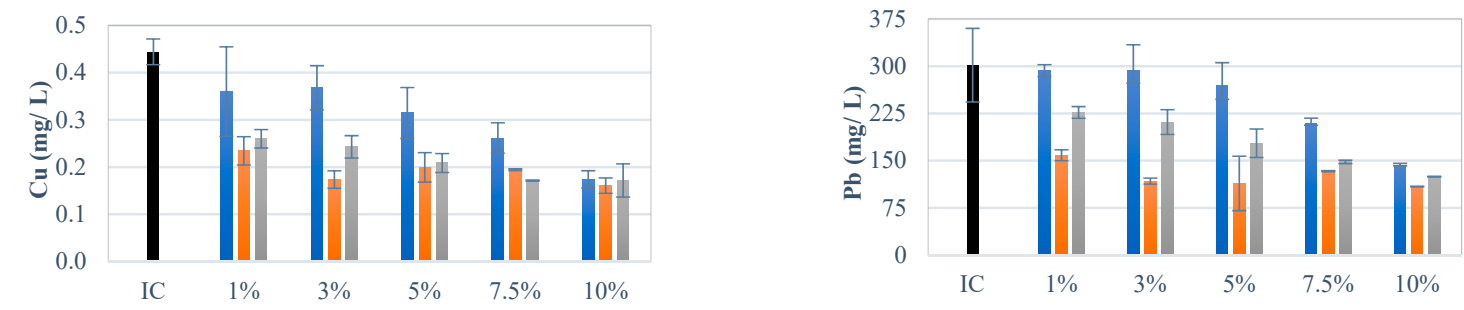

(c) Handmade contaminated soils (HCS)

- OS

ㄱ

RM

Figure 3. Toxic metal concentrations in $\mathrm{mg} / \mathrm{L}$ (from the TCLP test results of the silty sand soil, sandy soil and HCS). (ICInitial concentration; OS-Oyster shell; Z-zeolite; RM-Red mud). The number after the binder abbreviation represents mass percentage (e.g., Z3 means $3 \mathrm{wt} \%$ of zeolite). (Refer to Tables S5-S7 in the supplementary document for the descriptive statistics of these values). 


\subsubsection{Case II: Sandy Soil from a Military Service Area}

Meanwhile, the sandy soil had an initial $\mathrm{pH}$ between 6.55 and 6.85 . When mixed with oyster shell, zeolite and red mud, $\mathrm{pH}$ changed to 7.59-8.04, 6.25-6.58 and 7.90-9.48, respectively (Table S2). The addition of oyster shell and red mud increased the $\mathrm{pH}$ of the medium, whereas the addition of zeolite reduced the $\mathrm{pH}$ of the medium. In the case of red mud, $\mathrm{pH}$ increase was significant.

Initially, the sandy soil was slightly contaminated with $\mathrm{Zn}(201.060 \mathrm{mg} / \mathrm{kg})$ on the basis of the Korean, Canadian, Australian $(<200 \mathrm{mg} / \mathrm{kg})[27,66]$ and WHO $(<50 \mathrm{mg} / \mathrm{kg})$ [67] regulations, as presented in Table S4. Other toxic metal concentrations (Figures 3 and S3) were under the guideline values. Zn concentrations in the leachate were below the maximum permissible level for all the soil samples stabilised with $5 \mathrm{wt} \%$ dosage of any of the binders considered in this study. With a $5 \mathrm{wt} \%$ dosage of oyster shell, zeolite and red mud, $\mathrm{Zn}$ immobilisation rates of $50 \%, 37 \%$ and $32 \%$ were observed, respectively, as shown in Figure S1. In the case of zeolite, increasing the dosage after $1 \mathrm{wt} \%$ did not improve the immobilisation of toxic metals. The addition of high dosages of red mud increased $\mathrm{Pb}$ concentration by a factor close to two. Although $\mathrm{Cu}$ was below the relevant guideline values, our findings implied that applying oyster shell, zeolite and red mud immobilised $86 \%, 27 \%$ and $37 \%$ of $\mathrm{Cu}$, respectively. Overall, oyster shell exhibited the highest immobilisation rate for all the toxic metals considered in this study.

\subsubsection{Case III: Handmade Contaminated Soil (HCS)}

HCS, which is also sandy soil, had an initial pH between 4.75 and 5.05. After mixing with oyster shell, zeolite and red mud, its $\mathrm{pH}$ changed to 6.91-7.51, 4.42-5.18 and 6.23-9.63, respectively (Table S2). Compared with the initial $\mathrm{pH}$ values, the addition of oyster shell and red mud increased the $\mathrm{pH}$ of HCS. By contrast, the addition of zeolite at dosages lower than $5 \%$ decreased $\mathrm{pH}$ slightly whilst dosages over $5 \%$ increased $\mathrm{pH}$ marginally.

The leachate with DI water presented an initial $\mathrm{Pb}$ concentration of $301.65 \mathrm{mg} / \mathrm{L}$. Conversely, the leaching test with TCLP reported a mean $\mathrm{Pb}$ concentration of $159.802 \mathrm{mg} / \mathrm{L}$ as the initial concentration of HCS. This value is lower than the concentrations obtained by leaching with DI water. This finding can be attributed to the aging effect (short time). The results suggested that $\mathrm{Pb}$ concentration can be reduced by $62 \%$ by adding $5 \mathrm{wt} \%$ of zeolite. However, the final concentration $(113.825 \mathrm{mg} / \mathrm{L})$ was still higher than Korean and international regulations $(<5 \mathrm{mg} / \mathrm{L}$, Table S4). Meanwhile, $\mathrm{Pb}$ concentration in the leachate was reduced to $269.942 \mathrm{mg} / \mathrm{L}$ ( $11 \%$ of Pb was immobilised) after administering oyster shell and $177.637 \mathrm{mg} / \mathrm{L}$ ( $41 \%$ of $\mathrm{Pb}$ was immobilised) after administering red mud at $5 \mathrm{wt} \%$ dosage. However, when dosage was increased to $10 \mathrm{wt} \%$, the immobilisation rate via oyster shell addition significantly improved. By contrast, such an improvement in binder performance was not observed with zeolite when its dosage was increased. After adding $10 \mathrm{wt} \%$ of oyster shell, zeolite and red mud, $\mathrm{Pb}$ immobilisation rates of $53 \%, 64 \%$ and $59 \%$, respectively, were observed (Figures 3 and $\mathrm{S} 4$ ).

The initial $\mathrm{Cu}$ concentration was lower than the maximum permissible levels. However, after adding $5 \mathrm{wt} \%$ of oyster shell, zeolite and red mud, $29 \%, 55 \%$ and $53 \%$ of $\mathrm{Cu}$, respectively, were immobilised. When dosage was increased to $10 \mathrm{wt} \%$, the immobilisation rates increased to $61 \%, 63 \%$ and $61 \%$, respectively. Similar to the observations for $\mathrm{Pb}$, the increment in immobilisation by oyster shell was significant when dosage was increased (Figure S1).

\subsection{Effect of Contact Time}

When silty sand soil with moderate toxic metal pollution level was mixed with oyster shell, $\mathrm{Pb}$ concentration decreased immediately, immobilising up to $70 \% \mathrm{of} \mathrm{Pb}$; thereafter, it did not improve with increasing contact time (Figure S5). A similar phenomenon was observed for $\mathrm{Zn}$ and $\mathrm{Cu}$. The immobilisation rates of $\mathrm{Zn}$ and $\mathrm{Cu}$ in this soil sample stabilised with zeolite and red mud improved with longer contact time. Zeolite and red mud exhibited constant performance in stabilising $\mathrm{Pb}$ at different contact times. 
For HCS soil stabilised with oyster shell, the high $\mathrm{Pb}$ concentration in the leachate was reduced to $38.769 \mathrm{mg} / \mathrm{L}$ ( $87 \%$ of $\mathrm{Pb}$ was immobilised) after 1 day of contact time and $94 \%$ of $\mathrm{Pb}$ was immobilised after 10 days at dosages above 5\% (Figures 4 and S6). However, these values were still above the regulation level. When HCS was treated with oyster shell at $10 \mathrm{wt} \%$, the $\mathrm{Pb}$ concentration in the leachate collected after 1 day was $3.67 \mathrm{mg} / \mathrm{L}$, which is slightly above the Korean regulation but under the maximum value of $5 \mathrm{mg} / \mathrm{L}$ stipulated by U.S. EPA. At short contact times (e.g., $12 \mathrm{~h}$ ), oyster shell with dosages up to $5 \%$ immobilised less than $10 \%$ of $\mathrm{Pb}$. After 1 day, oyster shell apparently reached maximum $\mathrm{Cu}$ and $\mathrm{Pb}$ stabilisation because the authors did not observe any significant improvement in immobilisation.
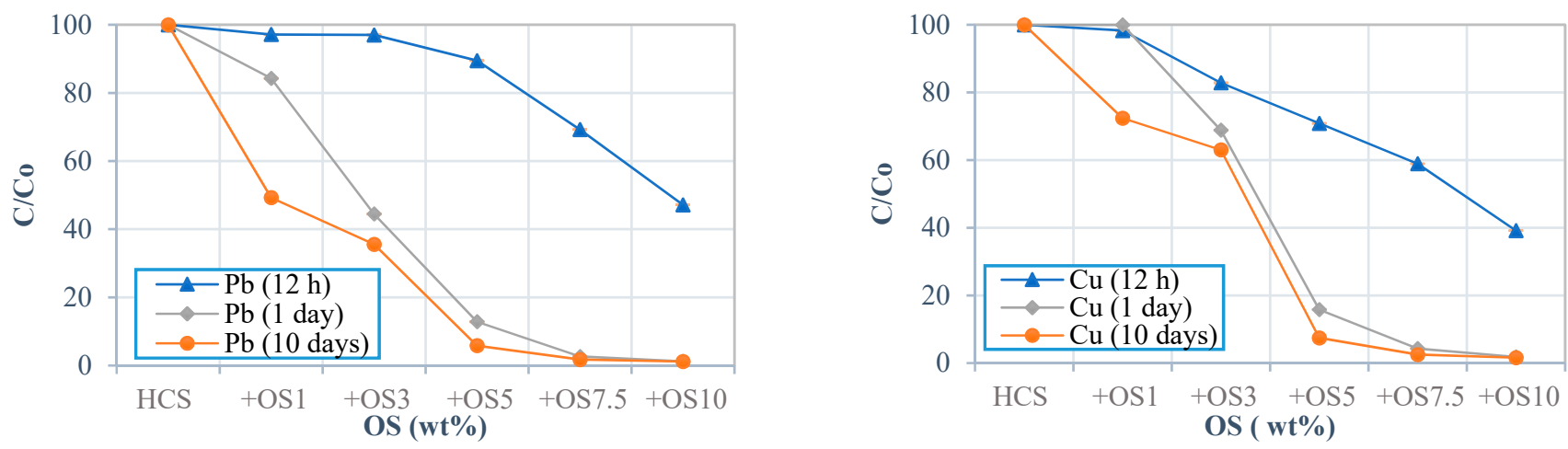

Figure 4. $\mathrm{Pb}$ and $\mathrm{Cu}$ concentrations in the HCS treated with oyster shell obtained through the TCLP test at different contact times (12 h, 1 day and 10 days). (The number after the binder abbreviation represents mass percentage (e.g., OS3 means $3 \mathrm{wt} \%$ of oyster shell). (Refer to Table S8).

\section{Discussion}

\subsection{Oyster Shell Powder}

Oyster shell powder demonstrated the best performance in binding nearly all the considered toxic metals, particularly $\mathrm{Pb}$ and $\mathrm{Cu}$, for the silty sand and sandy soil samples. Furthermore, our observations suggested that the preference for sorption of oyster shell was in the following order: $\mathrm{Pb}^{2+}>\mathrm{Cu}^{2+}>\mathrm{Zn}^{2+}>\mathrm{Cd}^{2+}>\mathrm{Ni}^{2+}$. This order is similar to the observations of Shin et al. [41] in their kinetic model. In addition, when HCS was treated with oyster shell, all the samples had a $\mathrm{pH}$ above 7 (alkaline). $\mathrm{CaCO}_{3}$ and $\mathrm{CaO}$ in oyster shell were dissolved in water to produce hydroxyl ions $\left(\mathrm{OH}^{-}\right)$, increasing the $\mathrm{pH}$ of the medium $\left(\mathrm{CaCO}_{3}+\mathrm{H}_{2} \mathrm{O} \rightarrow \mathrm{Ca}^{2+}+\mathrm{CO}_{3}{ }^{2-} ; \mathrm{CO}_{3}{ }^{2-}+\mathrm{H}_{2} \mathrm{O} \rightarrow \mathrm{HCO}_{3}\right.$ $+\mathrm{OH}^{-}$) [68]. This alkaline condition can promote the precipitation of metals as metal hydroxides $\left[\mathrm{M}^{\mathrm{n}+}+\mathrm{n}(\mathrm{OH})^{-} \rightarrow \mathrm{M}(\mathrm{OH})_{n}\right.$, where $\mathrm{M}$ denotes metal] [68,69], and can be linked to the reduction of toxic metals in leachate. Furthermore, the SEM-EDS analysis (Figure 5) showed that oyster shell exhibited high adsorption capacity towards $\mathrm{Pb}$ compared with the other binders considered in this study (SEM analysis results for other binder doses are presented as Figure S7). This finding can be attributed to ion exchange capacity [30]. The two aforementioned phenomena can justify the significant reduction $(p<0.05)$ in $\mathrm{Pb}$ with increased oyster shell dosage and contact time. The number of sorption sites and reactive hydroxide ions increased with oyster shell dosage, significantly reducing toxic metal concentrations $(p<0.05)$, as illustrated in Figures S2-S4 (descriptive statistics pertaining to the concentrations of toxic metals at different binder dosages are presented in Tables S5-S8). In the case of HCS treated with 5\% oyster shell dosage, only 30\% of Cu and $10 \%$ of $\mathrm{Pb}$ were immobilised. When dosage was increased to $10 \%$, sorption sites and metal precipitates were consequently increased and immobilisation rate reached up to $60 \%$ for $\mathrm{Cu}$ and $55 \%$ for $\mathrm{Pb}$. 

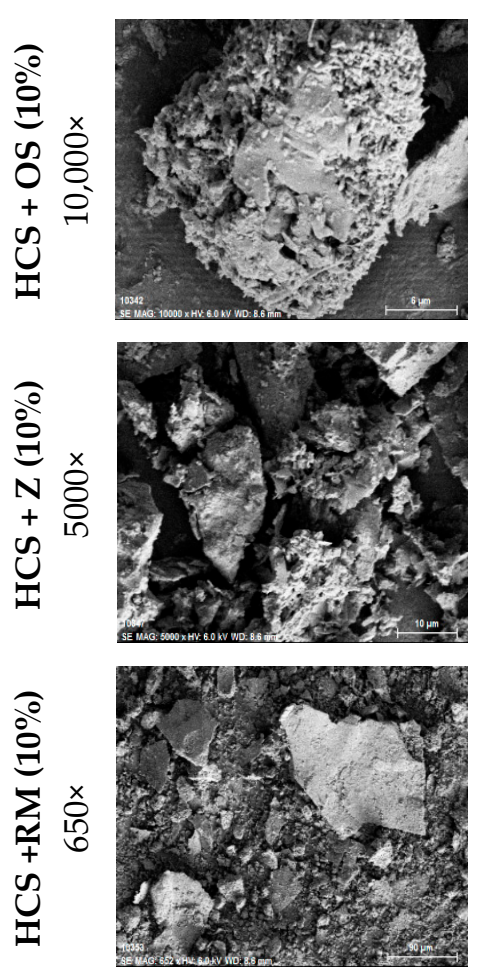
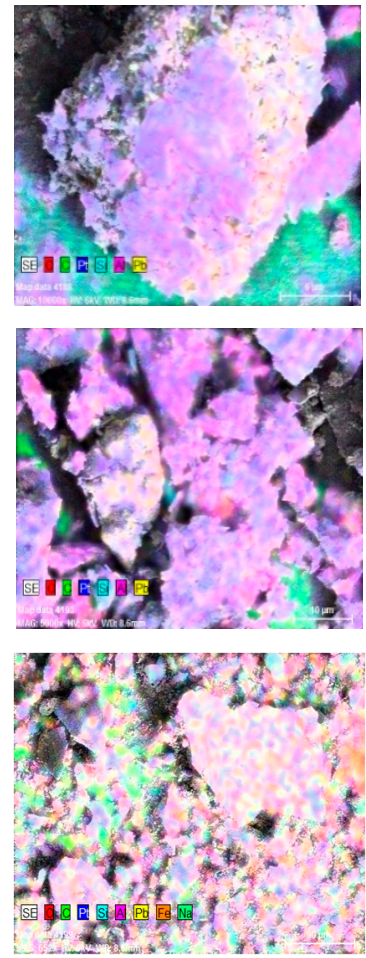
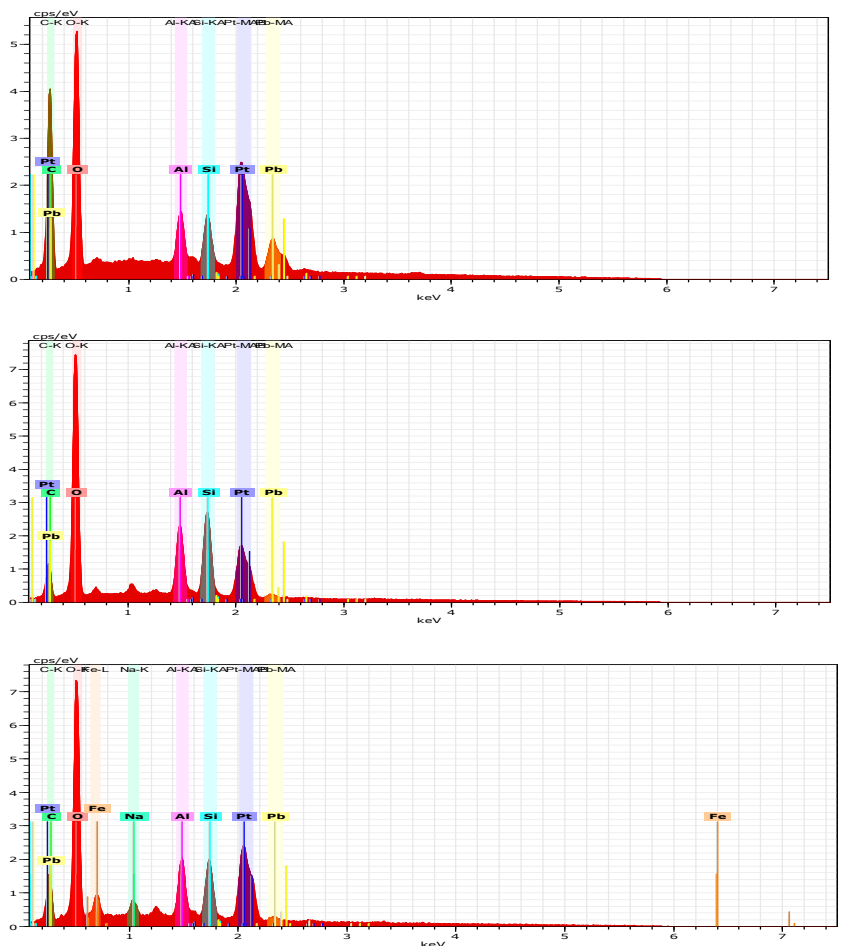

Figure 5. SEM-EDS analysis result for HCS treated with $10 \mathrm{wt} \%$ oyster shell, zeolite, and red mud.

Furthermore, the results of $\mathrm{Pb}$ and $\mathrm{Cu}$ concentrations in the HCS leachate stabilised with oyster shell over time. Figure 4 shows that better immobilisation of these toxic metals can be achieved with increasing contact time. The effect of contact time seemed insignificant for dosages over $5 \%$ and the change in immobilisation rate was insignificant $(p>0.05)$ for contact times beyond 1 day. This finding was also observed in silty sand soil, as illustrated in Figure S1. The preceding results corroborate the findings of Xu, et al. [42] and Desta [63], who observed the roles played by the adsorption characteristics and ion exchange capacity of binders and the precipitation of ions in achieving stabilisation over time. Considering that the immobilisation rate was maintained without significant variation, oyster shell can be used to stabilise a wide range of soil types; silty sand, sandy soil and HCS. Although oyster shell exhibited good performance in binding toxic metals, the treatment of soil that is highly polluted with $\mathrm{Pb}$ is recommended only for industrial areas where the percolation of water can be controlled. In addition, oyster shell contains sodium, which may be harmful to flora in excessive dosages. However, appropriate doses of oyster shell can be used as soil amendment for agricultural soil $[69,70]$.

\subsection{Zeolite}

In the current study, zeolite-treated soil had a neutral $\mathrm{pH}$ of approximately 6.5 and zeolite did not drastically change the $\mathrm{pH}$ of the medium. A slight increase in $\mathrm{pH}$ was observed when zeolite dosage was increased. Such $\mathrm{pH}$ conditions are beneficial for stabilisation by zeolite because the major binding mechanisms of zeolite are adsorption and cation exchange $[68,69]$. This phenomenon can be observed in HCS soil (a slightly acidic soil) wherein zeolite achieved the best immobilisation compared with the other binders at a contact time of $12 \mathrm{~h}$. Moreover, given that the immobilisation rate does not improve with dosage, we can argue that ion exchange is the primary binding mechanism of zeolite in our study. The surface of zeolite is negatively charged through the isomorphous replacement of $\mathrm{Al}^{+}$by $\mathrm{Al}^{3+}$. This negative charge can be balanced by exchangeable cations, such as $\mathrm{Na}, \mathrm{K}$ and $\mathrm{Ca}$. These exchangeable cations are used in ion exchange with metals ions, such as $\mathrm{Pb}, \mathrm{Cd}, \mathrm{Zn}$ and $\mathrm{Cu}[34,50,71]$. The number of exchangeable metal ions in soil did not change with increased dosage, and ion exchange may not occur because the activity 
of metal ions in the medium became considerably low. When exchangeable $\mathrm{Pb}$ ions are high in HCS, even a low dosage of $1 \%$ zeolite can bind $50 \%$ of Pb because of this high ion exchange capacity.

The leachates obtained for silty sand and sandy soil with DI water indicated that the addition of zeolite significantly reduced the concentrations of $\mathrm{Pb}$ and $\mathrm{Cu}$ (Figure S1); however, the immobilisation rate was lower compared with that of oyster shell. This result may be attributed to the low activity of the ions present in the soil. Furthermore, the final concentrations of toxic metals in the leachates of silty sand and sandy soil at $5 \mathrm{wt} \%$ were in the following order: $\mathrm{Pb}<\mathrm{Cu}<\mathrm{Zn}$. This finding corroborates zeolite's selectivity for cation exchange, i.e., $\mathrm{Pb}^{2+}>\mathrm{Cu}^{2+}>\mathrm{Zn}^{2+}$ [26]. Zeolite can be applied to soil near military bases or industries that is contaminated with a high amount of $\mathrm{Pb}$ or to acidic soil. In the current study, the authors only observed the performance after a contact time of $12 \mathrm{~h}$. Therefore, observing the long-term performance of zeolite is necessary because ion exchange is a reversible process in zeolite.

\subsection{Red $M u d$}

Red mud has an alkaline nature because of the presence of $\mathrm{NaOH}$, a strong base used in producing alumina [72]. The high alkalinity of red mud can increase $\mathrm{pH}$ drastically as we observed in this study. As shown in Figure 3, red mud is effective for highly contaminated soil, such as HCS. Shin, et al. [41] reported that red mud has a larger surface area than oyster shell and zeolite, and this characteristic improves the adsorption capacity (primary components: silica, alumina and $\mathrm{Fe}_{2} \mathrm{O}_{3}$ ) and ion exchange capacity of this material. This characteristic may be the reason for the previous observation. Furthermore, red mud can be used to precipitate soluble toxic metals in their hydroxide form. Therefore, a higher red mud dosage will result in higher stabilisation of $\mathrm{Pb}$, as observed in Figure 3, particularly for HCS soil. In sandy soil, a higher Cd concentration was observed after treatment, suggesting that $\mathrm{Cd}$ is adsorbed poorly in a competitive environment because red mud can exchange $\mathrm{Cd}$ ions in soil with Al compounds. Red mud was ineffective for soil with low contamination, such as sandy soil. In fact, the addition of red mud was counterproductive, particularly in the case of $\mathrm{Pb}$. This finding may be ascribed to the increase in $\mathrm{pH}$ and the dissolved organic carbon in soil pore water [73,74]. Dissolved organic carbon can enhance the leaching of $\mathrm{As}, \mathrm{Cu}$ and $\mathrm{Ni}$ from red mud when the latter comes in contact with organic-rich media [52], such as the silty sand soil evaluated in this study.

Considering the presence of water-soluble $\mathrm{Al}$ concentrations in red mud, biologically available $\mathrm{Al}$ can be released into the surrounding environment; in its acutely toxic form, i.e., $[\mathrm{Al}(\mathrm{OH}) 4]^{-}, \mathrm{Al}$ can pose considerable environmental and health hazards [73]. Therefore, the application of red mud to fertilised soil is not recommended.

\section{Conclusions}

The S/S technique aims to immobilise contaminants by converting them into a less soluble form (chemical stabilisation) and encapsulating them by creating a durable matrix (solidification), as observed through $\mathrm{pH}$ measurements after mixing the binder. From the results, binder performance changed depending on the type and level of toxic metal concentration (HCS > silty sand soil > sandy soil), and the $\mathrm{pH}$ of the final medium. These factors are associated with the solubility and mobilisation of toxic metals. When the medium was alkaline, better binding was observed amongst all the binders, emphasising the role of $\mathrm{OH}^{-}$ions in aiding the precipitation of toxic metals.

Oyster shell demonstrated the best performance in binding $\mathrm{Pb}$ and $\mathrm{Cu}$ in the silty sand soil and sandy soil (including $\mathrm{Cd}$ and $\mathrm{Ni}$ ), and its effect was immediately observable after adding $3 \%$ of the binder to soil samples with low-to-medium contamination levels. Moreover, oyster shell proved to be a good binder even for soil with an extremely high $\mathrm{Pb}$ concentration (i.e., $\mathrm{HCS}$ ). However, higher dosages $(>5 \%)$ and longer contact times ( $>1$ day) are required to achieve the desired immobilisation rates. Therefore, OS can be used to stabilise soils contaminated with of $\mathrm{Pb}$ and $\mathrm{Cu}$. 
Zeolite is a good alternative binder for highly contaminated soils (even under acidic condition) because of its cation exchange capacity with toxic metals and sorption properties. However, no significant improvement in binding performance can be achieved with doses above $3 \%$. In this experiment, the leaching agent was in contact for only $12 \mathrm{~h}$; thus, observing the performance of zeolite in a long-term setting is recommended. Red mud can be used alternatively to Zeolite. However, caution should be taken during its application because of the risk of releasing other metalloids. However, the performance of both Zeolite and Red mud is not reliable compared to Oyster shell.

The infiltration of acid rain may decrease soil $\mathrm{pH}$, leading to the mobilisation of bound toxic metals. Therefore, investigating the effect of $\mathrm{pH}$ and conducting a column percolation test prior to recommending any applications are recommended because most of the binders demonstrate better binding properties under alkaline conditions, particularly at low dosages.

For future studies, the authors suggest investigating whether the surface area of binders can be increased by subjecting them to high temperatures. Furthermore, biotic redox reactions, which are important for controlling oxidation state, were not considered in the current study. Thus, how the mobilisation of toxic metals is affected by such reactions requires investigation.

Supplementary Materials: The following are available online at https://www.mdpi.com/1660-460 $1 / 18 / 5 / 2530 /$ s1, Figure S1. Mean toxic metal concentrations measured in the leachate after mixing the binder with the silty sand soil from an abandoned metal mine site (Source: 1st year report of project 'grant no. 2019002470002'). S-Soil sample; IC-Initial concentration; OS-Oyster shell; Z-zeolite; RM-Red mud. The number after the binder abbreviation represents mass percentage (e.g. Z3 means $3 \mathrm{wt} \%$ of Z). Figure S2. Normalised final toxic metal concentrations in the leachates of silty sand soil, sandy soil and HCS obtained through the TCLP test. Figure S3. Variation in toxic metal concentrations in the leachate obtained via TCLP from the silty sand soil treated with OS, Z and RM. S-Soil sample; IC-Initial concentration; OS-Oyster shell; Z-zeolite; RM-Red mud. The number after the binder abbreviation represents mass percentage (e.g. $Z 3$ means $3 \mathrm{wt} \%$ of $Z$ ). Figure S4. Variation in toxic metal concentrations in the leachate obtained via the TCLP test of the sandy soil treated with OS, Z and RM. S-Soil sample; IC-Initial concentration; OS-Oyster shell; Z-zeolite; RM—Red mud. The number after the binder abbreviation represents mass percentage. Figure S5. Variation in toxic metal concentrations in the leachate obtained via the TCLP test of the HCS treated with OS, Z and RM. OS-Oyster shell; Z—zeolite; RM-Red mud. The number after the binder abbreviation represents mass percentage (e.g. Z3 means $3 \mathrm{wt} \%$ of $Z$ ). Figure $\mathrm{S} 6 . \mathrm{Pb}$ and $\mathrm{Cu}$ concentrations in the leachate obtained through the TCLP test of the HCS treated with OS at different extraction (contact) times. OS-Oyster shell. The number after the binder abbreviation represents mass percentage. Figure S7. SEM Analysis for the sample of soil treated with each binder $(5,7.5$ and $10 \mathrm{wt.} \%)$. Table S1. Chemical compositions of the silty sand soil, sandy soil and HCS; the binders, namely, oyster shell (OS), zeolite (Z) and red mud (RM) observed via X-ray fluorescence analysis. Table S2. $\mathrm{pH}$ value of the fine granular contaminated soils considered in this study after the addition of binders (OS, $\mathrm{Z}$ and $\mathrm{RM}$ ) at various dosages. Table $\mathrm{S} 3 . \mathrm{pH}$ value of the fine granular contaminated soils considered in this study treated with binders after leaching test via TCLP was performed. Table S4. Initial toxic metal concentrations in the considered soil samples and relevant permissible and guideline limits. Table S5. Descriptive statistics of toxic metal concentrations obtained via TCLP test from the leachate of silty sand soil treated with OS, Z and RM. Table S6. Variation in toxic metal concentrations in the leachate obtained via TCLP from sandy soil treated with OS, Z and RM. Table S7. Descriptive statistics of the toxic metal concentration for the leachate of HCS obtained from the TCLP test. Table S8. Descriptive statistics of the toxic metal concentration for the leachate of HCS obtained from the TCLP test when the supernatant was extracted at different times after treatment with oyster shell. References $[27,65-67,75-77]$ are cited in the supplementary materials.

Author Contributions: Conceptualization, C.T.-Q. and J.P.; data curation, C.T.-Q. and J.D.; formal analysis, C.T.-Q. and J.D.; funding acquisition, J.P.; investigation, C.T.-Q.; methodology, C.T.-Q.; project administration, J.P.; resources, J.P.; software, J.D.; supervision, J.P.; validation, C.T.-Q., J.D. and J.P.; visualization, C.T.-Q.; writing—original draft, C.T.-Q.; writing—review and editing, J.D. All authors have read and agreed to the published version of the manuscript. 
Funding: This research was supported by the Korea Ministry of Environment as part of the 'Subsurface Environmental Management' project: Grant No. 2019002470002.

Institutional Review Board Statement: Not applicable.

Informed Consent Statement: Not applicable.

Data Availability Statement: Data can be made available upon request.

Acknowledgments: Furthermore, the authors would like to thank $\mathrm{Xu}$ Xin, who worked in the beginning of this project. We are also grateful to BK21 PLUS research. Besides, authors like to acknowledge the support by Institute of Construction and Environmental Engineering at Seoul National University.

Conflicts of Interest: The authors declare no conflict of interest.

\section{References}

1. Hu, Y.; Liu, X.; Bai, J.; Shih, K.; Zeng, E.Y.; Cheng, H. Assessing heavy metal pollution in the surface soils of a region that had undergone three decades of intense industrialization and urbanization. Environ. Sci. Pollut. Res. 2013, 20, 6150-6159. [CrossRef] [PubMed]

2. Selvi, A.; Rajasekar, A.; Theerthagiri, J.; Ananthaselvam, A.; Sathishkumar, K.; Madhavan, J.; Rahman, P.K.S.M. Integrated Remediation Processes Toward Heavy Metal Removal/Recovery from Various Environments-A Review. Front. Environ. Sci. 2019, 7. [CrossRef]

3. Bünemann, E.K.; Bongiorno, G.; Bai, Z.; Creamer, R.E.; De Deyn, G.; de Goede, R.; Fleskens, L.; Geissen, V.; Kuyper, T.W.; Mäder, P.; et al. Soil quality-A critical review. Soil Biol. Biochem. 2018, 120, 105-125. [CrossRef]

4. Ma, J.; Chen, Y.; Antoniadis, V.; Wang, K.; Huang, Y.; Tian, H. Assessment of heavy metal(loid)s contamination risk and grain nutritional quality in organic waste-amended soil. J. Hazard. Mater. 2020, 399, 123095. [CrossRef] [PubMed]

5. Wang, F.; Guan, Q.; Tian, J.; Lin, J.; Yang, Y.; Yang, L.; Pan, N. Contamination characteristics, source apportionment, and health risk assessment of heavy metals in agricultural soil in the Hexi Corridor. Catena 2020, 191. [CrossRef]

6. Kumar, S.; Prasad, S.; Yadav, K.K.; Shrivastava, M.; Gupta, N.; Nagar, S.; Bach, Q.-V.; Kamyab, H.; Khan, S.A.; Yadav, S.; et al. Hazardous heavy metals contamination of vegetables and food chain: Role of sustainable remediation approaches-A review. Environ. Res. 2019, 179, 108792. [CrossRef]

7. U.S. EPA. General Principles for Performing Aggregate Exposure and Risk Assessments; U.S. Environmental Protection Agency: Washington, DC, USA, 2001.

8. $\quad$ ATSDR. Draft Toxicological Profile for Lead; ATSDR: Atlanta, GA, USA, 2005.

9. Jung, M.C. Contamination by $\mathrm{Cd}, \mathrm{Cu}, \mathrm{Pb}$, and $\mathrm{Zn}$ in mine wastes from abandoned metal mines classified as mineralization types in Korea. Environ. Geochem. Health 2008, 30, 205-217. [CrossRef]

10. NJDEP. Technical Guidance on the capping of sites undergoing remediation. In Site Remediation Program; New Jersey Department of Environmental Protection (NJDEP): Trenton, NJ, USA, 2014.

11. Khan, F.I.; Husain, T.; Hejazi, R. An overview and analysis of site remediation technologies. J. Environ. Manag. 2004, 71, 95-122. [CrossRef] [PubMed]

12. Kutuniva, J.; Mäkinen, J.; Kauppila, T.; Karppinen, A.; Hellsten, S.; Luukkonen, T.; Lassi, U. Geopolymers as active capping materials for in situ remediation of metal(loid)-contaminated lake sediments. J. Environ. Chem. Eng. 2019, 7, 102852. [CrossRef]

13. FHWA. INDOT Guidance Document for In-Situ Soil Flushing; Joint Transportation Research Program, Indiana Department of Transportation and Purdue University: West Lafayette, IN, USA, 2007.

14. Dermont, G.; Bergeron, M.; Mercier, G.; Richer-Laflèche, M. Soil washing for metal removal: A review of physical/chemical technologies and field applications. J. Hazard. Mater. 2008, 152, 1-31. [CrossRef]

15. Andreozzi, R.; Fabbricino, M.; Ferraro, A.; Lerza, S.; Marotta, R.; Pirozzi, F.; Race, M. Simultaneous removal of Cr(III) from high contaminated soil and recovery of lactic acid from the spent solution. J. Environ. Manag. 2020, 268, 110584. [CrossRef] [PubMed]

16. Kim, W.S.; Kim, S.O.; Kim, K.W. Enhanced electrokinetic extraction of heavy metals from soils assisted by ion exchange membranes. J. Hazard. Mater. 2005, 118, 93-102. [CrossRef]

17. Tang, J.; He, J.; Tang, H.; Wang, H.; Sima, W.; Liang, C.; Qiu, Z. Heavy metal removal effectiveness, flow direction and speciation variations in the sludge during the biosurfactant-enhanced electrokinetic remediation. Sep. Purif. Technol. 2020, 246. [CrossRef]

18. U.S. EPA. Resource Guide for Electrokinetics Laboratory and Field Processes Applicable to Radioactive and Hazardous Mixed Wastes in Soil and Groundwater from 1992 to 1997; U.S. Environmental Protection Agency: Washington, DC, USA, 1997; p. 83.

19. Hunce, S.Y.; Akgul, D.; Demir, G.; Mertoglu, B. Solidification/stabilization of landfill leachate concentrate using different aggregate materials. Waste Manag. 2012, 32, 1394-1400. [CrossRef]

20. Xia, W.-Y.; Du, Y.-J.; Li, F.-S.; Li, C.-P.; Yan, X.-L.; Arulrajah, A.; Wang, F.; Song, D.-J. In-situ solidification/stabilization of heavy metals contaminated site soil using a dry jet mixing method and new hydroxyapatite based binder. J. Hazard. Mater. 2019, 369, 353-361. [CrossRef] [PubMed] 
21. Du, Y.-J.; Liu, S.-Y.; Liu, Z.-B.; Chen, L.; Zhang, F.; Jin, F. An Overview of Stabilization/Solidification Technique for Heavy Metals Contaminated Soils. In Advances in Environmental Geotechnics; Chen, Y., Zhan, L., Tang, X., Eds.; Springer: Berlin/Heidelberg, Germany, 2010; pp. 760-766.

22. Meegoda Jay, N.; Ezeldin, A.S.; Fang, H.-Y.; Inyang Hilary, I. Waste Immobilization Technologies. Pract. Period. Hazard. Toxic Radioact. Waste Manag. 2003, 7, 46-58. [CrossRef]

23. Shu, X.; Li, Y.; Huang, W.; Chen, S.; Xu, C.; Zhang, S.; Li, B.; Wang, X.; Qing, Q.; Lu, X. Rapid vitrification of uranium-contaminated soil: Effect and mechanism. Environ. Pollut. 2020, 263, 114539. [CrossRef]

24. Ali, H.; Khan, E.; Sajad, M.A. Phytoremediation of heavy metals-Concepts and applications. Chemosphere 2013, 91, 869-881. [CrossRef] [PubMed]

25. Chandra, R.; Dubey, N.K.; Kumar, V. Phytoremediation of Environmental Pollutants; CRC Press: Boca Raton, FL, USA, 2018.

26. Babel, S.; Kurniawan, T.A. Low-cost adsorbents for heavy metals uptake from contaminated water: A review. J. Hazard. Mater. 2003, 97, 219-243. [CrossRef]

27. Liu, L.; Li, W.; Song, W.; Guo, M. Remediation techniques for heavy metal-contaminated soils: Principles and applicability. Sci. Total Environ. 2018, 633, 206-219. [CrossRef] [PubMed]

28. Paria, S.; Yuet, P.K. Solidification-stabilization of organic and inorganic contaminants using Portland cement: A literature review. Environ. Rev. 2006, 14, 217-255. [CrossRef]

29. Yakubu, Y.; Zhou, J.; Ping, D.; Shu, Z.; Chen, Y. Effects of pH dynamics on solidification/stabilization of municipal solid waste incineration fly ash. J. Environ. Manag. 2018, 207, 243-248. [CrossRef] [PubMed]

30. Zhong, G.; Liu, Y.; Tang, Y. Oyster shell powder for Pb(II) immobilization in both aquatic and sediment environments. Environ. Geochem. Health 2020. [CrossRef]

31. Zheng, S.-a.; Zheng, X.; Chen, C. Leaching Behavior of Heavy Metals and Transformation of Their Speciation in Polluted Soil Receiving Simulated Acid Rain. PLoS ONE 2012, 7, e49664. [CrossRef]

32. Xia, W.-Y.; Feng, Y.-S.; Jin, F.; Zhang, L.-M.; Du, Y.-J. Stabilization and solidification of a heavy metal contaminated site soil using a hydroxyapatite based binder. Constr. Build. Mater. 2017, 156, 199-207. [CrossRef]

33. Zhang, L.; Zeng, Y.; Cheng, Z. Removal of heavy metal ions using chitosan and modified chitosan: A review. J. Mol. Liq. 2016, 214, 175-191. [CrossRef]

34. Erdem, E.; Karapinar, N.; Donat, R. The removal of heavy metal cations by natural zeolites. J. Colloid Interface Sci. 2004, 280, 309-314. [CrossRef]

35. Kargar, M.; Clark, O.G.; Hendershot, W.H.; Jutras, P.; Prasher, S.O. Immobilization of Trace Metals in Contaminated Urban Soil Amended with Compost and Biochar. Water Air Soil Pollut. 2015, 226. [CrossRef]

36. Ma, W.; Chen, D.; Pan, M.; Gu, T.; Zhong, L.; Chen, G.; Yan, B.; Cheng, Z. Performance of chemical chelating agent stabilization and cement solidification on heavy metals in MSWI fly ash: A comparative study. J. Environ. Manag. 2019, 247, 169-177. [CrossRef] [PubMed]

37. Silva, T.H.; Mesquita-Guimarães, J.; Henriques, B.; Silva, F.S.; Fredel, M.C. The Potential Use of Oyster Shell Waste in New Value-Added By-Product. Resources 2019, 8, 13. [CrossRef]

38. Lu, J.; Cong, X.; Li, Y.; Hao, Y.; Wang, C. Scalable recycling of oyster shells into high purity calcite powders by the mechanochemical and hydrothermal treatments. J. Clean. Prod. 2018, 172, 1978-1985. [CrossRef]

39. Wang, P.; Liu, D.-Y. Physical and Chemical Properties of Sintering Red Mud and Bayer Red Mud and the Implications for Beneficial Utilization. Materials 2012, 5, 1800-1810. [CrossRef]

40. Han, Y.S.; Ji, S.; Lee, P.K.; Oh, C. Bauxite residue neutralization with simultaneous mineral carbonation using atmospheric $\mathrm{CO}_{2}$. J. Hazard. Mater. 2017, 326, 87-93. [CrossRef]

41. Shin, W.-S.; Kang, K.; Kim, Y.-K. Adsorption Characteristics of Multi-Metal Ions by Red Mud, Zeolite, Limestone, and Oyster Shell. Environ. Eng. Res. 2014, 19, 15-22. [CrossRef]

42. Xu, X.; Liu, X.; Oh, M.; Park, J. Oyster Shell as a Low-Cost Adsorbent for Removing Heavy Metal Ions from Wastewater. Pol. J. Environ. Stud. 2019, 28, 2949-2959. [CrossRef]

43. Jeong, S.H.; Lim, J.E.; Lee, S.S.; Chang, Y.Y.; Moon, D.H.; Ok, Y.S. Evaluation on remediation efficiency on Acid-Spilled soil using Oyster Shell and Biochar. J. Agric. Life Sci. 2013, 25, 10-16.

44. Moon, D.H.; Park, J.W.; Cheong, K.H.; Hyun, S.; Koutsospyros, A.; Park, J.H.; Ok, Y.S. Stabilization of lead and copper contaminated firing range soil using calcined oyster shells and fly ash. Environ. Geochem. Health 2013, 35, 705-714. [CrossRef] [PubMed]

45. Lim, J.E.; Moon, D.-H.; Kim, D.; Kwon, O.-K.; Yang, J.E.; Ok, Y.S. Evaluation of the Feasibility of Oyster-Shell and Eggshell Wastes for Stabilization of Arsenic-Contaminated Soil. J. Korean Soc. Environ. Eng. 2009, 31, 1095-1104.

46. Ouki, S.K.; Kavannagh, M. Performance of Natural Zeolites for the treatments of mixed metal-Contaminated Effluents. Waste Manag. Res. 1997, 15, 383-394. [CrossRef]

47. Grant, D.C.; Skriba, M.C.; Saha, A.K. Removal of radiactive contaminants from West Valley Waste Streams using Natual Zeolites. Environ. Prog. 1987, 6. [CrossRef]

48. Zamzow, M.J.; Eichbaum, B.R.; Sandgren, K.R.; Shanks, D.E. Removal of Heavy Metals and Other Cations from Wastewater Using Zeolites. Sep. Sci. Technol. 1990, 25, 1555-1569. [CrossRef] 
49. Parades-Aguilar, J.; Reyes-Martinez, V.; Bustamante, G.; Almendariz-Tapia, F.J.; Martinez-Meza, G.; Vilchez-Vargas, R.; Link, A.; Certucha-Barragan, M.T.; Calderon, K. Removal of nickel(II) from wastewater using a zeolite-packed anaerobic bioreactor: Bacterial diversity and community structure shifts. J. Environ. Manag. 2020, 111558. [CrossRef]

50. Kwon, P.S.; Shahrokhi-shahraki, R.; Park, J.B. Assessment of Zeolite Soil Mixture as Adsorptive Fill Material at Industrial Zones. J. Korean Soc. Civ. Eng. 2019, 39, 203-209. [CrossRef]

51. Wen, J.; Zeng, G. Chemical and biological assessment of Cd-polluted sediment for land use: The effect of stabilization using chitosan-coated zeolite. J. Environ. Manag. 2018, 212, 46-53. [CrossRef] [PubMed]

52. Ujaczki, É.; Klebercz, O.; Feigl, V.; Molnár, M.; Magyar, Á.; Uzinger, N.; Gruiz, K. Environmental Toxicity Assessment of the Spilled Ajka Red Mud in Soil Microcosms for Its Potential Utilisation as Soil Ameliorant. Period. Polytech. Chem. Eng. 2015, 59, 253-261. [CrossRef]

53. KIGAM. JP2014-008-2015 Recycling of Red Mud as a Landfill cover Material and a Stabilizer of Acid Mine Tailing Generated from a Working Mine; Korean Institute of Geoscience and Mineral Resources: Daejeon, Korea, 2015.

54. Watts, R.J. Hazardous Wastes: Sources, Pathways, Receptors; Wiley: Hoboken, NJ, USA, 1998; p. 764.

55. Du, Y.J.; Wei, M.L.; Reddy, K.R.; Liu, Z.P.; Jin, F. Effect of acid rain pH on leaching behavior of cement stabilized lead-contaminated soil. J. Hazard. Mater. 2014, 271, 131-140. [CrossRef] [PubMed]

56. Martini, S.A.; Shang, J.Q. Monitoring Lead in Soil Water System Using Complex Permittivity. In Proceedings of the 8th International Conference on Environment Science and Engineering (ICESE 2018), Barcelona, Spain, 11-13 March 2018; IOP Publishing Ltd.: Barcelona, Spain, 2018.

57. MEPC. HJ-557-2010 Solid Waste-Extraction Procedure for Leaching Toxicity-Horizontal Vibration Method; Ministry of Environmental Protection of the People's Republic of China: Beijing, China, 2010.

58. U.S. EPA. METHOD 1311 Toxicity characteristic Leaching Procedure. In Hazardous Waste Test Methods; U.S. Environmental Protection Agency: Washington, DC, USA, 1992.

59. Lu, C.-C.; Hsu, M.H.; Lin, Y.-P. Evaluation of heavy metal leachability of incinerating recycled aggregate and solidification/stabilization products for construction reuse using TCLP, multi-final $\mathrm{pH}$ and EDTA-mediated TCLP leaching tests. J. Hazard. Mater. 2019, 368, 336-344. [CrossRef]

60. Sahuquillo, A.; Rigol, A.; Rauret, G. Comparison of leaching tests for the study of trace metals remobilization in soils and sediments. J. Environ. Monit. 2002, 4, 1003-1009. [CrossRef]

61. EHTI. No. 2018-53 Standards for Soil Pollution Process. In ES 07400.2c Metals-Inductively Coupled Plasma-Atomic Emission Spectrometry; Environmental Health Technology Institute: Seoul, Korea, 2018.

62. Saca, N.; Dimache, A.; Radu, L.R.; Iancu, I. Leaching behavior of some demolition wastes. J. Mater. Cycles Waste Manag. 2017, 19, 623-630. [CrossRef]

63. Desta, M.B. Batch Sorption Experiments: Langmuir and Freundlich Isotherm Studies for the Adsorption of Textile Metal Ions onto Teff Straw (Eragrostis tef) Agricultural Waste. J. Thermodyn. 2013, 2013, 375830. [CrossRef]

64. U.S. EPA. METHOD 200.7 Determination of Metals and Trace Elements in Water and Wastes by Inductively Coupled Plasma-Atomic Emission Spectrometry; U.S. Environmental Protection Agency: Washington, DC, USA, 1994.

65. U.S. EPA. 40 CFR 261.24-Toxicity Characteristic; Environmental Protection Agency: Washington, DC, USA, 2011.

66. EHTI. No. 2017-54 Waste Process Test Standard. In ES 06002.a Standards, Labeling Limits and Result Indication of Hazardous Substances Contained in Designated Waste—2014; Environmental Health Technology Institute: Seoul, Korea, 2017.

67. WHO. Permessible Limits for Heavy Metals in Soils and Plants; World Health Organization (WHO): Geneva, Switzerland, 1996.

68. Ok, Y.S.; Oh, S.-E.; Ahmad, M.; Hyun, S.; Kim, K.-R.; Moon, D.H.; Lee, S.S.; Lim, K.J.; Jeon, W.-T.; Yang, J.E. Effects of natural and calcined oyster shells on $\mathrm{Cd}$ and Pb immobilization in contaminated soils. Environ. Earth Sci. 2010, 61, 1301-1308. [CrossRef]

69. Bonnard, M.; Boury, B.; Parrot, I. Key Insights, Tools, and Future Prospects on Oyster Shell End-of-Life: A Critical Analysis of Sustainable Solutions. Environ. Sci. Technol. 2020, 54, 26-38. [CrossRef] [PubMed]

70. Lee, C.H.; Lee, D.K.; Ali, M.A.; Kim, P.J. Effects of oyster shell on soil chemical and biological properties and cabbage productivity as a liming materials. Waste Manag. 2008, 28, 2702-2708. [CrossRef] [PubMed]

71. Zhang, L.; Zhang, L.; Dong, X.; Zhang, S.; Zhao, Y.; Cen, Q.; Zhang, K. The effect and mechanism of Si/Al ratio on microstructure of zeolite modified ceramsite derived from industrial wastes. Micropor. Mesopor. Mat. 2021, 311. [CrossRef]

72. Cui, Y.; Chen, J.; Zhang, Y.; Peng, D.; Huang, T.; Sun, C. pH-Dependent Leaching Characteristics of Major and Toxic Elements from Red Mud. Int. J. Environ. Res. Public Health 2019, 16, 2046. [CrossRef] [PubMed]

73. Mayes, W.M.; Burke, I.T.; Gomes, H.I.; Anton, Á.D.; Molnár, M.; Feigl, V.; Ujaczki, É. Advances in Understanding Environmental Risks of Red Mud After the Ajka Spill, Hungary. J. Sustain. Metall. 2016, 2, 332-343. [CrossRef]

74. Anton, A.; Rékási, M.; Uzinger, N.; Széplábi, G.; Makó, A. Modelling the Potential Effects of the Hungarian Red Mud Disaster on Soil Properties. Water Air Soil Pollut. 2012, 223, 5175-5188. [CrossRef]

75. Buchman, M.F. NOAA Screening Quick Reference Tables; NOAA OR\&R Report 08-1; Seattle, WA, USA, 2008; p. 34. Available online: https: / / repository.library.noaa.gov/view/noaa/9327 (accessed on 10 November 2020).

76. CCME Canadian Environmental Quality Guideline. Available online: http://st-ts.ccme.ca/en/index.html (accessed on 13 November 2020).

77. MEPC. GB 5085.3-2007 Identification Standards for Hazardous Wastes_Identification for Extraction Toxicity; Ministry of Environmental Protection of the People's Republic of China: Beijing, China, 2007. 